IRA-International Journal of Applied Sciences ISSN 2455-4499; Vol.03, Issue 03 (2016)

\title{
Influence of Supplementation of Zea Mays Flour on the Growth and Economic Traits of Silkworm, Bombyx Mori L.(PFD)
}

\author{
Shifa Vanmathi. J \\ Assistant Professor \\ Department Of Animal Science \\ Manonmaniam Sundaranar University \\ Tirunelveli -627011, Tamilnadu, India.
}

DOI: http://dx.doi.org/10.21013/jas.v3.n3.p17

\section{How to cite this paper:}

J, S. (2016). Influence of Supplementation of Zea Mays Flour on the Growth and Economic Traits of Silkworm, Bombyx Mori L.(PFD). IRA-International Journal of Applied Sciences (ISSN 2455-4499), 3(3). doi:http://dx.doi.org/10.21013/jas.v3.n3.p17

(C) Institute of Research Advances

\section{(cc) BY-No}

This works is licensed under a Creative Commons Attribution-Non Commercial 4.0

International License subject to proper citation to the publication source of the work.

Disclaimer: The scholarly papers as reviewed and published by the Institute of Research Advances (IRA) are the views and opinions of their respective authors and are not the views or opinions of the IRA. The IRA disclaims of any harm or loss caused due to the published content to any party. 


\section{ABSTRACT}

Studies were carried out on the impact of supplementation of Zea mays flour on silkworm Bombyx mori belonging to double hybrid variety (PFD). The $3^{\text {rd }}, 4^{\text {th }} 5^{\text {th }}$ instars larvae were feed with leaves supplemented with different concentrations of Zea mays flour. Maximum larval weight was observed in $5^{\text {th }}$ instar larvae in $10 \%$ Treatment $(4.59 \pm 0.31 \mathrm{~g})$ and $5 \%$ Treatment $(3.98 \pm 0.23 \mathrm{~g})$ as compared to the control $(3.13 \pm 0.14 \mathrm{~g})$.Mulberry leaves treated with Zea mays flour protein (10\%)fed larvae recorded a maximum cocoon weight $(2.32 \pm 0.07 \mathrm{~g}$ ), pupal weight $(1.53 \pm 0.12 \mathrm{~g})$ shell weight $(0.42 \pm 0.02 \mathrm{~g})$, shell ratio $(24.55 \pm 0.62 \%)$ silk filament length $(851.11 \pm 6.94 m)$ silk filament weight $(0.51 \pm 0.04 \mathrm{~g})$. Shell ratio in this treatment (10\%) showed an increase of $18.38 \%$ over control filament length $21.64 \%$. Larvae fed with mulberry leaves enriched with Zea mays flour protein showed significant enchancement in economic characters of Bombyx mori was traced.

Keywords: Silkworm Bombyx mori L.(PFD), Zea mays flour, growth and economic traits

\section{INTRODUCTION:}

Silkworm Bombyx mori L.( Lepidoptera: Bombycidae), the source of fabulous Silk has been under domestication for the past 5000years India has a long tradition of producing and using Silk, "The Queen of fabrics". Sericulture today is practiced in industrially advanced countries such as Japan and Russia as well as in countries like china. India and south Korea are developing industrially (Bhattacharya and Kaliwal, 2003).

The leaves of Morus species are the sole source of the food for Silkworm, B.mori.L, and Nutritional quality of leaves plays a vital role in determining the health and growth of the larvae. The feeding of nutritionally enriched leaves showed better growth and development of Silkworm larvae, as well as directly influence on the quality and quantity of Silk production (Krishnaswami, et.al., 1971).

Fortification of mulberry leaves by using supplementary nutrient and feeding to the Silkworms is a useful modern technique to increase economic value of cocoon (Kumararaj et.al., 1972). The supplementation of extra nutrients along with mulberry leaves results higher yield because the production of superior quality and quantity of Silk depends mainly on nutritional status and healthiness of the larva.

(Horie and Watanabe 1983) showed that the supplementation of corn flour protein increased the protein and amino acid content in the larval haemolymph of the Silkworm B.mori . In recent years attempts have been made in sericulture with nutrients such as proteins, carbohydrades, amino acids, vitamins, hormones antibiotics etc. For better performance and to get high yield and quantity cocoons (Sannapa, et.al., 2002; Etebari, et al.,2004).

Larvae of $B$. mori were reared on various kinds of dietary protein (soybean, mushroom, corn flour and mixture of them) using semi-artificial diet. Larvae fed on semi-artificial diet containing corn flour all over the $5^{\text {th }}$ instar larvae gave the highest records on the larval duration, weights of larvae, silk gland, pupa, cocoon and cocoon shell, as well as number of deposited eggs. The same diet gave the lowest mortality percentages. (Mona Mahmoud, 2013)

Our present study focused to evaluate the effect of different concentrations of corn flour on the length, weight; economic characteristics of Silk worm namely cocoon 
weight, Shell weight, shell ratio, Silk filament length and Silk filament weight of Silk worm Bombyx mori L.

\section{MATERIALS AND METHODS}

\section{Collection and rearing of Bombyx mori $L$}

The Silk worm selected for the experiment was a popular double hybride variety (PFD) Bombyx mori L. (Lepidoptera:Bombycidae) and selected feed additive was Corn flour, Z. mays. The $3^{\text {rd }}$ instar batches of larvae stage of double hybride variety (PFD) Silkworms was obtained from the Government sericulture unit of Tamil Nadu Silk Board Rearing Centre, V.M. Chatram, Tirunelveli district. During the entire procedure of rearing, fresh mulberry leaves of MR2 variety were collected in the early morning and evening from the field and stored in wet gunny bags. The larvae were fed four times a day, at 6 a.m,11 a.m, 2 p.m, and 6 p.m. Chopped mulberry leaves were used according to the age of the larvae. Bed cleaning, spacing, feeding time were adopted carefully following the methods of Krishnaswami,1978.

The rearing room and appliances were thoroughly cleaned and the floor was washed with five per cent bleaching powder solution. The whole room was disinfected by spraying with 2.5 percent sanitech in 0.5 per cent slacked lime solution (Dandin et.al., 2003). Bed cleaning was done once during first instar and twice during second instar.. An optimum temperature of $25 \pm 1^{\circ} \mathrm{c}$ and $75 \pm 5 \%$ percent relative humidity was maintained through out the experimental period. The bottoms of the rearing trays were lined with paraffin paper and the edges with wet foam rubber strips. (Jolly,1986).

\section{Food supplements for young age Silkworm, Bombyx mori $L$}

The commercial Zea mays flour were purchased from the market and different concentrations of Zea mays flour suspensions were prepared in distilled water. The known quantity of mulberry leaves $(1 \mathrm{~kg})$ were dipped in corn flour suspension, air-dried and fed to the experimental groups from the first day of the $3^{\text {rd }}$ instar to the end of the $5^{\text {th }}$ instar. In experimental groups 30 larvae of $3^{\text {rd }}$ instar in each treatment fed with leaves sprayed with flour in two doses like 5\% (treatment 1) and $10 \%$ (treatment 2) respectively. One batch (45 larvae) of silkworm was fed with normal mulberry leaves (control) in three replications.

Studies were carried out on enriching the mulberry leaves with Zea mays flour to improve the Silkworm nutrition. In treatment -1 and 2 were the of leaves as first feed and normal control was fed with fresh mulberry leaves sprayed with distilled water only. This experiment was conducted in Completely Randomised Design (CRD) with three replications (Panse and Sukhatme,1957).

\section{Observations of economic characters of Silk worm, B.mori $L$.}

\section{a) Larval length and larval weight of Silk worm, B.mori $L$.}

To study the effect of feeding mulberry leaves enriched with different concentration of corn flour on the larval growth and larval weight of the Silkworm were observed on $3^{\text {rd }}, 4^{\text {th }}$ and $5^{\text {th }}$ instar (10 days) using a digital balance $(0.01 \mathrm{~g})$. Fifteen larvae from every replication were randomly selected and their mass recorded from which the average larval length and weight was observed ( Radjabi,et al.,2009).

\section{b) Cocoon characters of Silk worm, B.mori $L$.}

The matured $5^{\text {th }}$ instar larvae were mounted and the cocoons were harvested on fifth day. The commercial parameters such as cocoon weight, pupal weight, shell 
weight, shell ratio, Silk filament length, Silk filament weight were determined by the standard procedure (Sonwalker,1992).

\section{i) Cocoon, Pupa and cocoon shell weight:}

One week after pupation, the cocoons were harvested and cocoons in good condition were cut open from each batch. Male and female pupae were separated and cocoon, pupa and shell weight were recorded. The randomly selected cocoons were taken and weighed using an electronic balance and the weight was expressed in grams. After removing the floss, the cocoons were cut open and the pupae were taken out without causing any damage to them. Then the pupae were weighed using an electronic balance. The shell of the cocoon after removing the floss and pupa was weighed using an electronic balance (Balamani, et al., 1995)

\section{ii) Cocoon Shell percentage:}

The percentage of cocoon Shell was calculated using the following formula and expressed in percentage.

Cocoon Shell percentage $=$ Shell weight $/$ Cocoon weight $\times 100($ Waldbauer,1968)

\section{c) Observation of Silk characters of Silk worm, Bombyx mori $L$.}

Cocoon from each replication were stifled in boiling water and threads from individual cocoons were reeled using an eporouette and observed for their silk characters as silk filament length and silk filament weight.

Silk filament weight $=$

$$
\text { Number of rotation in eporouette }
$$

\section{Cocoon}

\section{Statistical Analysis:}

All the values were statistically analyzed and are presented as Mean \pm SD

\section{RESULTS AND DISCUSSION}

In the present study the results indicates that, the impact of different concentrations of Zea mays flour on growth and economic characters of Silk worm, Bombyx mori L.

(Lepidoptera:Bombycidae)

\section{Larval Length of Silk worm, Bombyx mori $L$.}

The effect of mulberry leaves enrichment with Zea mays flour treatment of an larval length is shown in (Table-1). In $3^{\text {rd }}$ instar, $4^{\text {th }}$ instar and $5^{\text {th }}$ instar period, the maximum larval length was observed in Treatment $2(10 \%)(3.22 \pm 0.07 \mathrm{~cm})$, $(4.2 \pm 0.26 \mathrm{~cm}),(8.6 \pm 0.06 \mathrm{~cm})$ followed by treatment $1(5 \%)(3.13 \pm 0.15 \mathrm{~cm})$ $(4.03 \pm 0.18 \mathrm{~cm}),(4.03 \pm 0.18 \mathrm{~cm})$ and minimum length was observed in control. $(3.11 \pm 0.04 \mathrm{~cm}),(4.01 \pm 0.26 \mathrm{~cm}) .(6.98 \pm 0.38 \mathrm{~cm})$ respectively. Highly significant gain in larval length was observed in treatment 2 followed by Treatment 1 similar to the report of Sarkar et.al., 1995.

\section{Larval Weight of Silk worm Bombyx mori $L$.}

The results pertaining to larval weight was found to be highly significant (Table-2). On $3^{\text {rd }}$ instar, the maximum larval weight was recorded in Treatment 2 $(0.52 \pm 0.01 \mathrm{~g}),(1.92 \pm 0.62 \mathrm{~g}),(4.59 \pm 0.31 \mathrm{~g})$ followed by Treatment $1(0.46 \pm 0.03 \mathrm{~g})$ $(1.59 \pm 0.17 \mathrm{~g})(3.98 \pm 0.23 \mathrm{~g})$ and control $(0.44 \pm 0.00 \mathrm{~g})(0.85 \pm 0.04 \mathrm{~g})(3.13 \pm 0.14 \mathrm{~g})$ respectively. Highly significant gain in larval weight was observed in Treatment 2 with $10 \%$ corn flour followed by Treatment 1 .The increase of body weight in treatment 2 may be due to the fortification of leaf with the feed corn flour supplement 
. Similar results were reported by El-Hattab, 2002 indicated that the $5^{\text {th }}$ instar larval fed on diet contained mulberry leaves with Corn flour gave the highest significant weights of larvae, silk glands and pupae

\section{Cocoon Characters of Silk worm, Bombyx mori $L$.}

The data represented in (Table 3) reveals that the economic parameters of Bombyx mori $L$.

\section{a) Cocoon Weight}

The cocoon weight was significantly higher in Treatment $2(10 \%)$ $(2.32 \pm 0.07 \mathrm{~g})$ followed by Treatment $1(5 \%)(2.12 \pm 0.20 \mathrm{~g})$ and lower in control $(1.34 \pm 0.13 \mathrm{~g})$. According to (Subbarao et.al,1989), mulberry leaves enriched with corn flour powder in two different concentration (5gm to $10 \mathrm{gm}$ ) helped to improved qualitative and quantitative characters of cocoon and fecundity.

\section{b)Pupal Weight}

The maximum pupal weight was noticed in Treatment $2(1.53 \pm 0.12 \mathrm{~g})$, followed by Treatment $1(1.41 \pm 0.36 \mathrm{~g})$ and compared to control $(1.06 \pm 0.10 \mathrm{~g})$. Ganga and Gowri 1990 also recorded improvement in larval weight, silk gland weight and commercial cocoon characters compared to the control and the optimum shell ratio in the cereal flours supplemented groups.

\section{c) Shell Weight}

The data pertaining to the shell weight are highly significant. Maximum shell weight was recorded in treatment $2(0.42 \pm 0.02 \mathrm{~g})$ followed by Treatment $1(0.39 \pm 0.02 \mathrm{~g})$ and minimum shell weight was observed in control $(0.33 \pm 0.03 \mathrm{~g})$. The main reason of nutritional supplementation for silk worms is to enhance the economic traits such as cocoon weight, cocoon shell weight and cocoon shell percentage. There are numerous reports containing the positive effects of nutritional supplementation on the economic traits of silkworm (Kabila, et.al.,1994,). (Etebari,2002) reported that a treatment with $2 \%$ ascorbic acid increased the cocoon weight and the shell weight of both male and female silkworm.

\section{d) Shell ratio}

Marked and significant increase in shell ratio was observed in control $(24.55 \pm 0.62 \%)$ followed by Treatment-1(18.80 $\pm 1.92 \%)$ and Treatment$2(18.38 \pm 0.71 \%)$. Shell weight and shell ratio are important criteria to be considered in the marketing of cocoon. Protein supplementation in the form of hydrolysed corn flour protein (Subburathinam and Krishnan,1998) was found to improved larval, cocoon, shell weight, cocoon/shell ratio, fecundity and haemolymph storage proteins.Lots of researchers fed silkworms mulberry leaves treated with different substances in order to obtain an increase in cocoon production.

\section{Silk Characters of Silk worm, Bombyx mori $L$.}

\section{a) Silk filament length}

The results indicated that the Treatment-2(851.11 $\pm 6.94 \mathrm{~m})$ showed maximum silk filament length compared to Treatment-1 $(755.00 \pm 5.00 \mathrm{~m})$ and Minimum silk filament length was recorded in control ( 660 $\pm 12.01 \mathrm{~m})$ (Table-4)

\section{b) Silk Filament weight}

The data showed that the maximum Silk filament weight was found in Treatment-2 ( $0.51 \pm 0.04 \mathrm{~g})$, and Treatment-1 $(0.42 \pm 0.01 \mathrm{gm})$. Minimum Silk filament weight was observed in control ( $0.32 \pm 0.03 \mathrm{gm})$ (Table-4).According to (Subbarao et.al.,1989) mulberry leaves enriched with corn flour powder in two different 
concentration ( $5 \mathrm{gm}$ to $10 \mathrm{gm}$ ) helped to improved qualitative and quantitative characters of cocoon and fecundity.

In conclusion, Zea mays flour was found to promote significant improvement in larval and cocoon characters of Silk worm Bombyx mori L Significant increase in economic characters like larval length, larval weight, cocoon weight and silk filament length of cocoon was observed in treatment with corn flour powder. The study proves the efficacy of corn flour treatment in silkworm rearing. As these materials are cheap and cost effective, they can be recommended for the farmers use 
TABLE:1

Effect of Zea mays flour on larval length (cm) of silkworm Bombyx mori $L$.

\begin{tabular}{|c|c|c|c|c|c|c|c|c|c|c|}
\hline \multirow[b]{2}{*}{ Treatment } & \multicolumn{10}{|c|}{ No. of days } \\
\hline & 1 & 2 & 3 & 4 & 5 & 6 & 7 & 8 & 9 & 10 \\
\hline & \multicolumn{3}{|c|}{$3^{\text {rd }}$ instar } & \multicolumn{3}{|c|}{$4^{\text {th }}$ instar } & \multicolumn{4}{|c|}{$5^{\text {th }}$ instar } \\
\hline Treatment 1 & $2.03 \pm 0.03$ & $2.11 \pm 0.46$ & $3.13 \pm 0.15$ & $3.69 \pm 0.17$ & $3.87 \pm 0.19$ & $4.03 \pm 0.18$ & $6.01 \pm 0.37$ & $6.18 \pm 0.39$ & $6.38 \pm 0.26$ & $8.15 \pm 0.14$ \\
\hline Treatment 2 & $2.06 \pm 0.05$ & $2.13 \pm 0.57$ & $3.22 \pm 0.07$ & $3.94 \pm 0.17$ & 4.05 \pm 0.17 & $4.2 \pm 0.26$ & $6.11 \pm 0.14$ & $6.32 \pm 0.18$ & $6.57 \pm 0.09$ & $8.6 \pm 0.06$ \\
\hline Control & $1.92 \pm 0.17$ & $2.05 \pm 0.11$ & $3.11 \pm 0.04$ & $3.57 \pm 0.09$ & $3.86 \pm 0.18$ & $4.01 \pm 0.26$ & $4.97 \pm 0.52$ & $5.19 \pm 0.44$ & $5.59 \pm 0.28$ & $6.98 \pm 0.38$ \\
\hline
\end{tabular}

TABLE: 2

Effect of Zea mays flour on larval weight (gm) of silkworm, Bombyx mori L.

\begin{tabular}{|c|c|c|c|c|c|c|c|c|c|c|}
\hline \multirow{3}{*}{ Treatment } & \multicolumn{10}{|c|}{ No. of days } \\
\hline & 1 & 2 & 3 & 4 & 5 & 6 & 7 & 8 & 9 & 10 \\
\hline & \multicolumn{3}{|c|}{$3^{\text {rd }}$ instar } & \multicolumn{3}{|c|}{$4^{\text {th }}$ instar } & \multicolumn{4}{|c|}{$5^{\text {th }}$ instar } \\
\hline Treatment 1 & $0.22 \pm 0.00$ & $\begin{array}{l}0.33 \pm 0.0 \\
2\end{array}$ & $\begin{array}{l}0.46 \pm 0.0 \\
3\end{array}$ & $0.51 \pm 0.06$ & $1.54 \pm 0.17$ & $\begin{array}{l}1.59 \pm 0.1 \\
7\end{array}$ & $1.67 \pm 0.63$ & $\begin{array}{l}2.13 \pm 0.1 \\
0\end{array}$ & $2.36 \pm 0.21$ & $3.98 \pm 0.23$ \\
\hline Treatment 2 & $0.25 \pm 0.01$ & $\begin{array}{l}0.35 \pm 0.0 \\
2\end{array}$ & $\begin{array}{l}0.52 \pm 0.0 \\
1\end{array}$ & $0.56 \pm 0.02$ & $1.76 \pm 0.18$ & $\begin{array}{l}1.82 \pm 0.1 \\
8\end{array}$ & $1.92 \pm 0.62$ & $\begin{array}{l}2.18 \pm 0.1 \\
2\end{array}$ & $3.37 \pm 0.68$ & $4.59 \pm 0.31$ \\
\hline Control & $0.17 \pm 0.37$ & $\begin{array}{l}0.27 \pm 0.0 \\
1\end{array}$ & $\begin{array}{l}0.44 \pm 0.0 \\
0\end{array}$ & $0.46 \pm 0.00$ & $0.69 \pm 0.13$ & $\begin{array}{l}0.85 \pm 0.0 \\
4\end{array}$ & $0.88 \pm 0.37$ & $\begin{array}{l}1.69 \pm 0.0 \\
6\end{array}$ & $2.02 \pm 0.14$ & $3.13 \pm 0.14$ \\
\hline
\end{tabular}

The experiment data was expressed as Mean \pm S.D. The mean difference is significant of the $p<005$ level. 
TABLE:3

Effect of corn flour administration on cocoon characters of Silkworm Bombyx mori $L$.

\begin{tabular}{|c|c|c|c|c|}
\hline Treatment & $\begin{array}{c}\text { Cocoon weight } \\
(\mathrm{gm})\end{array}$ & Pupal weight $(\mathrm{gm})$ & Shell weight $(\mathrm{gm})$ & Shell ratio $(\%)$ \\
\hline Treatment 1 & $\mathbf{2 . 1 2} \pm \mathbf{0 . 2 0}$ & $\mathbf{1 . 4 1} \pm \mathbf{0 . 3 6}$ & $\mathbf{0 . 3 9} \pm \mathbf{0 . 0 2}$ & \\
\hline Treatment 2 & $\mathbf{2 . 3 2} \pm 0.07$ & $\mathbf{1 . 5 3} \pm \mathbf{0 . 1 2}$ & $\mathbf{0 . 4 2} \pm 0.02$ & $18.80 \pm 1.92$ \\
\hline Control & $\mathbf{1 . 3 4} \pm 0.13$ & $1.06 \pm 0.10$ & $0.33 \pm 0.03$ & $24.55 \pm 0.62$ \\
\hline
\end{tabular}

TABLE:4

Effect of corn flour administration on silk characters of Silkworm Bombyx mori L.

\begin{tabular}{|c|c|c|}
\hline Treatment & Silk filament length $(\mathbf{m})$ & Silk filament weight $(\mathrm{g})$ \\
\hline Treatment 1 & $\mathbf{7 5 5 . 0 0 \pm 5 . 0 0}$ & $\mathbf{0 . 4 2} \pm \mathbf{0 . 0 1}$ \\
\hline Treatment 2 & $\mathbf{8 5 1 . 1 1} \pm 6.94$ & $\mathbf{0 . 5 1} \pm \mathbf{0 . 0 4}$ \\
\hline Control & $\mathbf{6 6 0 . 0 0} \pm 12.01$ & $\mathbf{0 . 3 2} \pm \mathbf{0 . 0 3}$ \\
\hline
\end{tabular}

The experiment data was expressed as Mean \pm SD. The mean difference is significant of

the $\mathrm{p}<005$ level

Influence of corn flour on Silk Parameters of Silk worm Bombyx mori L

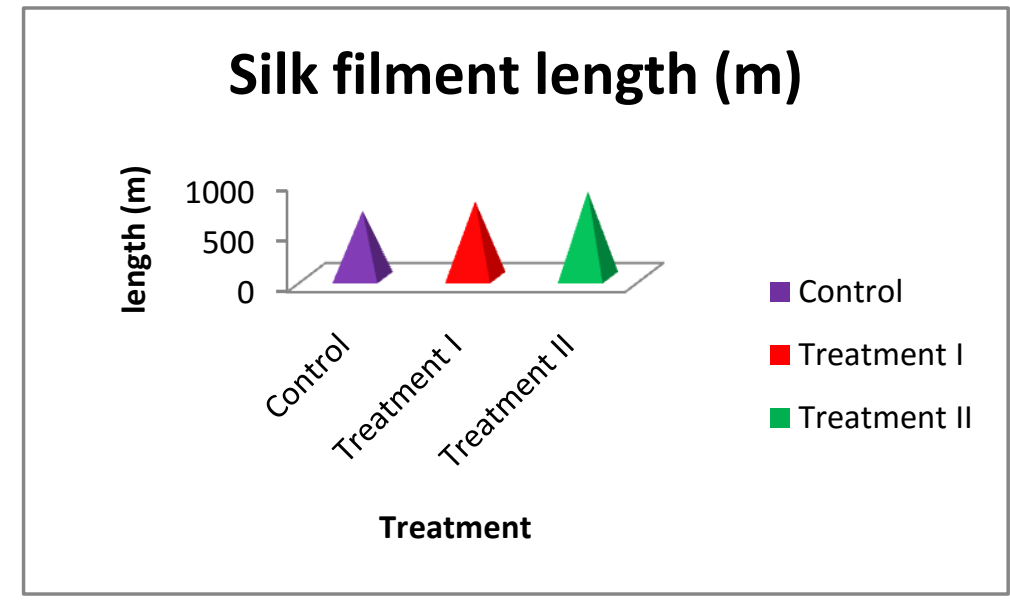

Influence of corn flour on Silk Filament weight (g) of Silk worm Bombyx mori $L$.

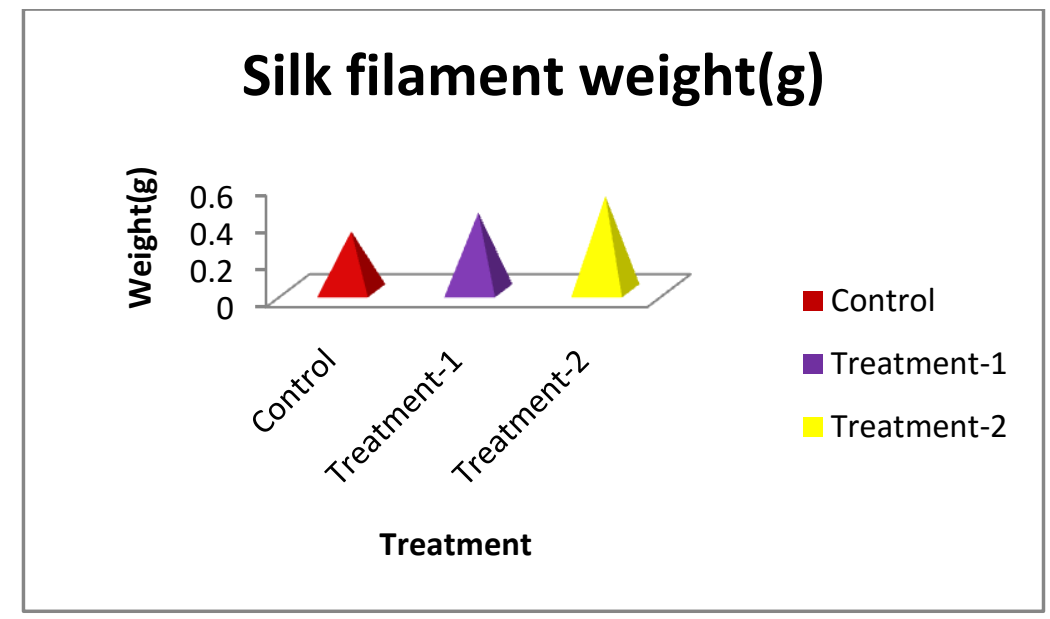




\section{References}

Balamani.R.,Prince.S.P.M., and Subbram.W.V.,(1995).Effect of zinc on the nutrional indices,economic characters of cocoon and quality of silk Bombyx mori.L 'Indian J.Seric. 3491069-71.

Bhattacharya.A., Kaliwal, B.B.,(2003). Influence on mineral potassium permanganate on the economic parameters of the silkworm, Bombyx mori L. Proceeding of National Conference on Tropical Sericulture for Global Competitiveness., 91.

Dandin.S.B., Jayant Jayaswal and Giridhar.K., (2003) .Handbook of sericulture technologies, Central Silk Board, Bangalore.

El-Hattab, Samia .M., (2002). Evaluation of various kinds of dietary proteins in semi artificial diets on the mulberry silkworm Bombyx mori L. ${ }^{\text {nd }}$ Int. conf., Plant Protection Res. Institute, Cairo, Egypt, 21 - 24 December.

Etebari.K., (2002). Effect of enrichment mulberry leaves ( Morus alba) with some vitamins and nitrogenous compounds on some economic traits and physiological characters of silkworm Bombyx mori.L. MSc Thesia, Isfahan University of Technology, Isfahan, Iran, pp: 150.

Etebari. K, Ebadi.R and Matindoost.L., (2004).Effect of feeding mulberry enriched leaves with ascorbic acid on some biological, biochemical and economical characteristics of silkworm Bombyx mori L. Int. J. Entomol., 8: 81-877.

Grimaldi.,David.A., Engel., and Michael .S. , (2005). Evolution of the

Insects. Cambridge University Press. ISBN 978-0-521-82149-0.

Horie.Y., and Watanabe.K., (1983).Effect of various levels of dietary protein and supplementation with limiting amino acids on growth, haemolymph components and uric acid excretion in silkworm, Bombyx mori L. J. Insect Physiol., 29 187-199.

Islam.R, Abdul.A, Dipak.P, Shaheen.S, Nilufa. B and Islam.R.,(2004) Effect of salt, nickel chloride supplementation on the growth of silkworm Bombyxmori L., Journal of Biological Science, 4: 170-172.

Jolly.M.S.,(1986). Pebrine and its control, CSR\&TI, Mysore, Bulletin No. 5.

Krishnaswami.S., Kumararaj.S., Vijayaraghavan.K., K. and Kasiviswanathan., (1971). Silkworm feeding trials for evaluating quality of mulberry leaves as influenced by variety, spacing and nitrogen Fertilizer, Indian J. Seri., 10: 79 $-86$.

Krishnaswami.S., (1978) New technology of silkworm rearing, Bull.No.2, central Sericultural Research and Training Institute, Central Silk Board, Bangalore, India. P.23.

Kumaraj.S,Vijayaraghavan.S and Krishnaswami. S., (1972). Studies on Fortification of mulberry leaves for feeding silkworms. Indian J. Seric.,11: 68 -72.

Mahmood,R, (1989). Effect of nitrogen on the larval development and silk yield of Bombyx mori L.in erlation to nutritional requirement. M.Sc. Hons Thesis, Dep. Agri. Entomol., Univ., Faisalabad, Pakistan.

Mona M. Mahmoud, (2013).Effect of various kinds of dietary proteins in semiartificial diets on the mulberry silk worm Bombyx mori L. Egypt. Acad.J.Biolog. Sci., 6(1):21-26.

Panse.V.G., and Sukhatme.P.V., (1957). Statistical Method for Agricultural Workers, ICAR Publication, New Delhi.

Radjabi.R., Ebadi.R., Mirhoseini.S.Z., and Nair.S., (2009) . Effects of Feeding Alanine-enriched Mulbery Leaves on the Economic characters of the Silkworm Bombyx mori ( Lepidoptera: Bombycidae ). Formosane ntomologist, 29:73-8.

Sannapa.B., Ramaiah.M.J., and Chandrappa.D., (2002) .Influence of castor genotype on consumption indices of eri silkworm sumia Cynthia ricini. Bioduval.Enviorn. Ecol., 20: 960-964. 
Sarkar.A.A., and Absarm.N., (1995) .Foliar treatment effect of urea and micronutrients on mulberry Morus sp.And silkworm Bombyx mori.Sericologia, 35:713-720..

Sonwalker. T.N., (1992) .Hand book of silk technology, 'Wiley Eastern

Limited. New Delhi: 4-62, (Book style).

Subburathinum.K.M, and Krishna.M.,(1998). "Role of Soya bean protein in silk worm nutrition," Indian silk, pp: 9-10.

Waldbauer.G.P., (1968). The consumption and utilization of food by insects, $A d v$. Insect Physiol., 5:229-288. 